\title{
Determination of Iron (Fe) and Calcium (Ca) in NIST SRM 1566b (Oyster tissue) using Flame Atomic Absorption Spectrometry (F-AAS) by Standard Addition Method
}

\author{
Fitri Dara, Y. Susanto Ridwan \\ Research Center for Chemistry-Indonesian Institute of Sciences \\ Jl. Cisitu-Sangkuriang Bandung 40135 \\ e-mail : fitrimusthapa@hotmail.com
}

\begin{abstract}
NIST Standard Reference Material (SRM 1566b) was employed for the determination of Iron (Fe) and Calcium (Ca) as nutrients in food matrix using Flame Atomic Absorption Spectrometry (F-AAS). The certified value of SRM 1566b for Fe and Ca are $205.8 \pm 6.8 \mathrm{mg} / \mathrm{kg}$ and $0.0838 \pm 0.0020(\%)$ or $838 \pm$ $20 \mathrm{mg} / \mathrm{kg}$, respectively. This certified values are based on results obtained by single primary method (Isotope Dilution Inductively Couple Plasma Mass Spectrometry) at NIST with confirmation by other methods at National Metrology Institute of P.R. China. This paper proposed a method for determination of $\mathrm{Fe}$ and $\mathrm{Ca}$ in food matrix as recommended by AOAC official with a little modification. The method was commenced from the destruction of all organic matter by dry oxidation before analysis by standard addition. Under optimum condition, the results of the determination of Fe and Ca in SRM 1566b were agreed well with the certificate value. This method would be useful for routine analysis in food testing laboratories.
\end{abstract}

Keywords : Standard Reference Material, SRM, Flame-AAS, Standard addition method..

\section{INTRODUCTION}

Besides toxic and harmful element, essential elements in food are given attention because the lack of them can result in serious malnutrition and potential diseases. As example, an iron deficiency leads to a reduced synthesis of haemoglobin and therefore, lower than normal haemoglobin in the red cells ${ }^{[1]}$. Other effects of iron deficiency include impaired intellectual development, decreased resistance to infection, and possibly increased susceptibility to lead and cadmium toxicity ${ }^{[2]}$. Calcium is considered as essential nutrient because of its importance in building and maintaining bones and its role in blood clotting and muscle contraction ${ }^{[3]}$. To ensure the reability, traceability, and comparability of analytical results, all of testing laboratories for food and food products are required to demonstrate the validity of the measurements and the accuracy of the measurement results.

Well-characterized reference materials are needed by laboratories in the food testing and nutrition communities to provide the traceability in measurement, as a crucial evidence of accuracy and to facilitate compliance with nutritional labeling laws ${ }^{[4,5]}$. NIST Standard Reference Material (SRM 1566b - oyster tissue) is one of the Certified Reference Material that often used for validation of measurement procedure in analysis of elements in food. The certified values for $\mathrm{Fe}$ and $\mathrm{Ca}$ are based on results obtained by single primary method (Isotope Dilution Inductively Couple Plasma Mass Spectrometry) at NIST with confirmation by the same method at National Metrology Institute of P.R. China ${ }^{[6]}$. This method cannot applied in routine analysis because of high cost. Indirect measurements using Flame Atomic Absorption Spectrometry (F-AAS) or Graphite Furnace Atomic Absorption Spectrometry (GFAAS) by calibration curves with three or five standard solution are commonly carried out for elemental analysis in the food testing laboratories. 
In this work, we developed a single point standard addition method using flame atomic absorption spectrometry (F-AAS) for determination of Iron (Fe) and Calcium (Ca) in NIST SRM 1566b.

\section{EXPERIMENTAL}

\section{Instrumentation}

A Zeeman Atomic Absorption Spectrometer Hitachi Z-5000 equipped with Zeeman background correction unit was used. FAAS was carried out using air-acetylene flame, the most sensitive analytical wavelengths 248.3 $\mathrm{nm}$ and $422.7 \mathrm{~nm}$ were chosen for $\mathrm{Fe}$ and Ca. The instrumental setting of the spectrofotometer for determination of $\mathrm{Fe}$ and $\mathrm{Ca}$ are given in Table 1.

Tabel 1. Instrument parameters used in the determination of Fe and Ca by F-AAS

\begin{tabular}{lcc}
\hline & Fe & Ca \\
\hline Wavelength (nm) & 248.3 & 422.7 \\
SlitWidth (nm) & 0.2 & 1.3 \\
Lamp Current (mA) & 15.0 & 10.0 \\
Flame type & Air- $\mathrm{C}_{2} \mathrm{H}_{2}$ & Air- $\mathrm{C}_{2} \mathrm{H}_{2}$ \\
Fuel flow (L/min) & 2.0 & 2.1 \\
Oxidant (L/min) & 15.0 & 17.0 \\
Oxidant (kPa) & 160 & 188 \\
Burner height (mm) & 7.5 & 5.0 \\
\hline
\end{tabular}

\section{Reagents}

The Standard Reference Material (SRM 1566b - Oyster Tissue) was obtained from National Institute of Standards and Technology (Gaithersburg, MD, USA), and maintained in a desicator in presence of silica gel. Certified Iron stock solution (RM 3126a) for instrument calibration was purcase from NIST, and Calcium stock solution was made from $\mathrm{CaCO}_{3}$ E-Merck. Acids for digestion such as $\mathrm{HCl}$ were purcase from E-Merck and $\mathrm{HNO}_{3}$ AAS Grade were purcase from Wako Pure Chemicals, Japan.
Lanthanum buffer solution were made from $\mathrm{La}_{2} \mathrm{O}_{3} \mathrm{BDH}$. Ultra pure water (with resistivity 18 $\mathrm{M} \Omega \mathrm{cm}$ ) for sample preparation and dillution of minerals stock solution were purified using Milli-Q plus 185 system.

\section{Procedures}

a. Sample Preparation

Sample preparation according to AOAC's recommended method. $0.6 \mathrm{~g}$ sample (Oyster Tissue) was weigh into a $40 \mathrm{~mL}$ porcelain crucible, heat crucible on hotplate for pre-ash by increasing temperature slowly to maximum. Final temperature on ceramic plate should then be about 300$350^{\circ} \mathrm{C}$ and then put crucible in muffle furnace at $525-550^{\circ} \mathrm{C}$ for at least 3-4 $\mathrm{h}$. Carbon residue in ash was removed by addition of a few drops of $9.0 \mathrm{M} \mathrm{HNO}_{3}$ and evaporated on hot plate, then return crucible back in furnace for $1 \mathrm{~h}$. White/grey or slightly colored ash indicated that samples is completely ashed. The ash was dissolved in hot $6.0 \mathrm{M} \mathrm{HCl}(2 \times 5 \mathrm{~mL})$, swirl crucible with care to ensuring that all ash comes into contact with acid. Transfer into $50 \mathrm{~mL}$ tall beaker glass, cover with watch glass and evaporate acid on hot plate to near dryness. Take up in $0.1 \mathrm{M} \mathrm{HNO}_{3}$ and transfer quantitatively into polyethylene bottle and weigh. The resulting sample solution was ready for measurement using Flame-AAS by standard addition method. Lanthanum buffer solution was used when measuring Ca.

b. Preparation of Iron (Fe) Standard Solution.

NIST Iron standard solution, SRM 3126a $(9,97 \pm 0,02 \mathrm{mg} / \mathrm{g})$ was used. More dilute standard solution were prepared by weighing and dilution with $0.1 \mathrm{M} \mathrm{HNO}_{3}$.

c. Preparation of Calcium (Ca) Standard Solution.

The calcium standard solution in $0.1 \mathrm{M}$ $\mathrm{HNO}_{3}$ was prepared by weighing $0.3881 \mathrm{~g}$ of pure $\mathrm{CaCO}_{3}$ anhidrous (after drying for 1 hour at $110^{\circ} \mathrm{C}$ ), dissolving in $0.1 \mathrm{M} \mathrm{HNO}_{3}$, evaporated slowly to near dryness and taken 
up in $103.3736 \mathrm{~g}$ of $0.1 \mathrm{M} \mathrm{HNO}_{3}$. The concentration of calcium is $1495.99 \pm 8,71$ $\mathrm{mg} / \mathrm{kg}$. More dilute standard solutions were prepared by weighing and dilution with $0.1 \mathrm{M} \mathrm{HNO}_{3}$.

d. Preparation of Lanthanum Buffer Solution

The lanthanum buffer solution was prepared by weighing $2.9319 \mathrm{~g}$ of $\mathrm{La}_{2} \mathrm{O}_{3}$, dissolving in $20 \mathrm{~mL}$ of $6 \mathrm{M} \mathrm{HCl}$ and heated slowly over a hotplate. More $6 \mathrm{M} \mathrm{HCl}(10 \mathrm{~mL})$ were added to warm lanthanum solution and taken up in $250 \mathrm{~mL}$ volumetric flask of aquamillipore.

\section{RESULT AND DISCUSSION}

Dry ashing is a suitable way for digesting oyster tissue samples prior to determination of Fe and Ca because they are not volatile metallic compounds. Although dry ashing consume more time than wet digestion, it consume less chemicals and the resulting ash can be dissolved in a small amount of diluent. This type of samples pretreatment also environmental friendly.

Six (6) independent determination were carried out for the Fe and Ca content in NIST SRM 1566b by single point standard addition method. Each sample and standard solution was measured 8 times. The concentration of analyte added must be more than 2 times its concentration in sample solution measured. As it can be seen in Table 2, a good reproducibility was achieved for both metals since RSD was less than $1.75 \%$ for iron determination and 3.01\% for calcium determination. The accuracy of the method was expressed as the percent of recovery. The accuracy of the studied method was good, and recoveries determined for iron ranged from 97.39 to $102.46 \%$ and for calcium from 95.57 to $103.93 \%$.
Table 2. Summary of results for determination of $\mathrm{Fe}$ and $\mathrm{Ca}$ in NIST SRM 1566b by F-AAS using standard addition method.

\begin{tabular}{lcccc}
\hline \multirow{2}{*}{$\begin{array}{l}\text { Sample } \\
\text { code }\end{array}$} & \multicolumn{4}{c}{ Element } \\
\cline { 2 - 5 } & $\mathrm{Fe}^{(\mathrm{a})}$ & $\begin{array}{c}\text { Recovery, } \\
\%\end{array}$ & $\mathrm{Ca}^{(\mathrm{a})}$ & Recovery,\% \\
\hline OT-01 & 204.9548 & 99.59 & 870.9459 & 103.93 \\
OT-02 & 208.2768 & 101.20 & 805.6043 & 96.13 \\
OT-04 & 206.2295 & 100.21 & 825.6726 & 98.53 \\
OT-05 & 200.4303 & 97.39 & 828.9118 & 98.92 \\
OT-06 & 210.8729 & 102.46 & 800.8829 & 95.57 \\
OT-C & 208.2131 & 101.17 & 831.0645 & 99.17 \\
Mean & 206.4962 & 100.34 & 827.1803 & 98.71 \\
RSD, \% & 1.74 & - & 3.01 & -
\end{tabular}

a Results are given in $\mathrm{mg}$ of $\mathrm{Fe}$ or $\mathrm{Ca}$ per $\mathrm{kg}$ of sample.

\section{CONCLUSIONS}

Determination of Iron (Fe) and Calcium (Ca) in NIST SRM 1566b using Flame Atomic Absorption Spectrometry (F-AAS) by standard addition method have done successfully. The value of Fe and Ca was found to be $206.5 \pm 9.01$ $\mathrm{mg} / \mathrm{kg}$ and $827.18 \pm 34.49 \mathrm{mg} / \mathrm{kg}$ respectively. This method would be useful for routine analysis in food testing laboratories eventhough the uncertainty more bigger than determination using IDMS.

\section{ACKNOWLEDGEMENTS}

Thanks to Dr. Julia Kantasubrata for supervision in uncertainty measurement, and Dra. Retno Yusiasih, MS for corrections in this paper.

\section{REFERENCES}

1. Anzano JM., Gonzalez P., 2000, Microchemical Journal 64: 141-145

2. Casarett \& Doull's., 2001, Toxicology, The Basic Science of Poisons, $6^{\text {th }}$ edition, McGrawHill, USA. 
3. Vidal MT., Pascual-Marti MC., Salvador A., Llabata A., 2002, Microchemical Journal 72: 221-228

4. Sharpless KE., Greenberg RR., Schantz MM., Welch MJ., Wise SA., and Ihnat M., 2004, Anal. Bioanal. Chem 378: 1161-1167

5. Kaarls R, 2010, RM 2010-Beijing International Symposium on Reference Materials, 3-4

6. National Institute of Standards and Technology, 2010, Certificate of Analysis, Standard Reference Material 1556b Oyster Tissue, Gaithersburg, USA.

7. Horwitz W.(Ed.), 2005, Official Methods of Analysis, $18^{\text {th }}$ edition, Gaithersburg, USA. 